\title{
The science communicator
}

\author{
Science and Controversy: A Biography of Sir \\ Norman Lockyer, Founder Editor of Nature \\ by A. J. Meadows \\ Macmillan Science: 2008. 352 pp. \\ $\$ 35.00, £ 24.99$
}

Norman Lockyer, the founder of Nature and an important transitional figure between the amateur and the professional scientist, was no stranger to controversy. In addition to his outstanding research skills in astrophysics and meteorology, he acquired a reputation for the pugnacious tenacity with which he fought for the intellectual credit due to him. His personality constituted a rich source of material for fellow scientists who, as was common in the nineteenth century, were also amateur poets.

With the following verse, James Clerk Maxwell, the first head of the Cavendish Laboratory at the University of Cambridge, UK, epitomized and framed the perceptions of Lockyer's persona for the rest of his life:

\section{And Lockyer, and Lockyer, \\ Gets cockier, and cockier; \\ For he thinks he's the owner \\ Of the solar corona.}

Lockyer's passion for science and the building of institutions to nurture it was not driven by the egotistical pursuit of fame. As someone who was committed to science as a vocation, Lockyer to use sociologist Max Weber's words on religion and capitalism, written in the same period was certainly no "specialist without spirit".

Lockyer's organizational skills were deftly deployed when he founded Nature in 1869 . He mobilized his abilities for social networking to ensure that the fledgling periodical survived against competitors such as Knowledge and Academy. The founder of Knowledge, Richard Proctor, aimed to involve the general public directly in scientific discussions through reader feedback, seeing his role as a 'conductor' rather than as an editor. Lockyer, by contrast, wanted Nature to promote a science that was accessible to the public, but that did not involve the public in the scientific discussions themselves. These competing visions of the nature and role of science led to several disputes between Lockyer the editor and Proctor the conductor.

Lockyer's vision for his new journal prevailed. During this period, science was slowly transformed from an amateurish pursuit enjoyed by

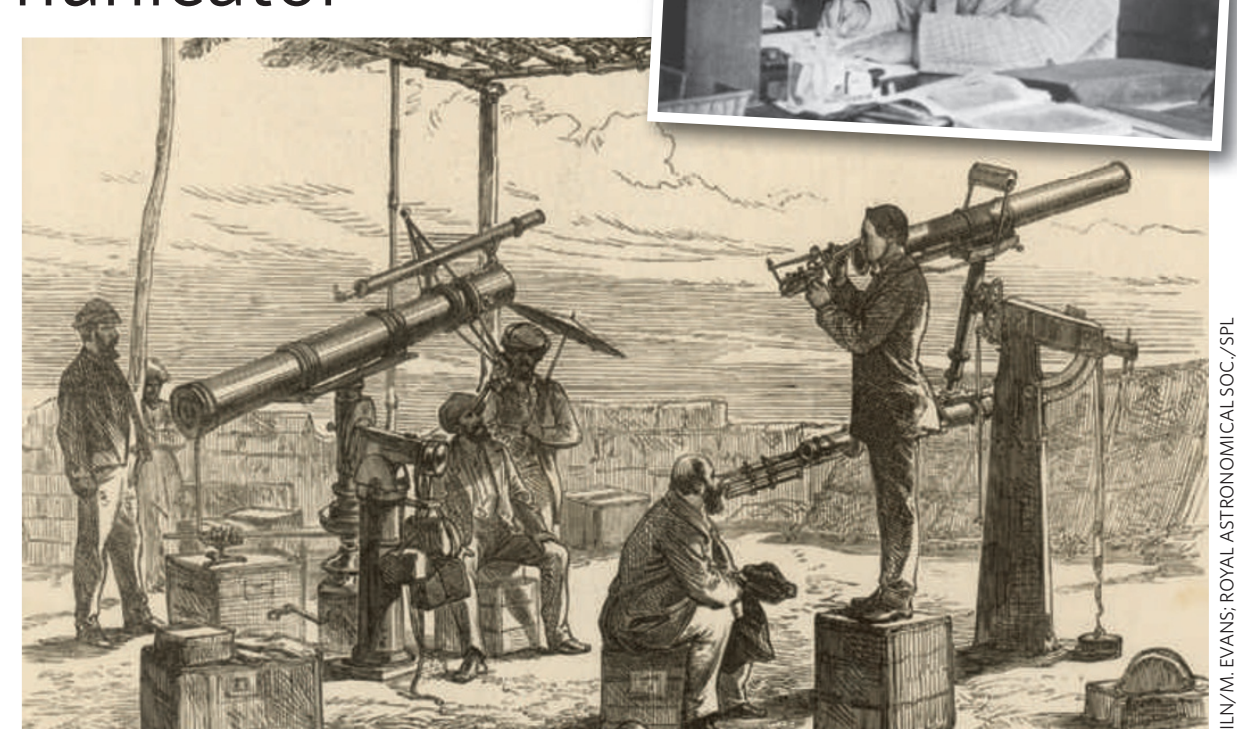

Personifying the gentleman scientist, Lockyer (inset, and seated left) helped create observatories in India.

people of means and leisure, to a professional activity. Its results were to be communicated to the public, but its practice would eventually be off limits to non-scientists. Lockyer intended Nature to play an active part in reconciling the divergent and the emergent tensions between science and the arts, amateurs and professionals, generalists and specialists. His goal was to capture the public's interest and imagination such that the British government might be persuaded to provide financial support for science. Lockyer's creation of the British Science Guild in 1905 played a similar role until the 1930s, when the organization withered away because, as A. J. Meadows points out, "the main elements of its policy became part of the general vision".

Like gentlemen scientists of the period, Lockyer's scientific interests were diverse, cut-

\section{"Lockyer wanted Nature} to promote science that was accessible, but that did not involve the public in scientific discussions." ting across the disciplinary boundaries that emerged and later became institutionalized. Meadows provides a detailed and riveting account of Lockyer's interests - from the orientation of ancient monuments, such as Stonehenge, to the influence of the Sun on terrestrial weather - focusing on Lockyer's important contributions to astronomical spectroscopy and astrophysics. The diverse contexts of Lockyer's work in India and Britain, and the controversies surrounding the identification and confirmation of the existence of helium (which Lockyer named) are significant elements of Meadows's absorbing narrative.

A particularly interesting and controversial episode in Lockyer's scientific career was his attempt to link terrestrial weather to sunspot cycles - a topic of extreme interest to administrators in the British Empire such as William Hunter, the director-general of statistics in India. Confronted by the country's devastating famines that were largely a consequence of specific policies, particularly the Permanent Settlement Act of 1793, administrators were keen to follow up and support Lockyer's conjecture of linking sunspot cycles to drought and famine. Despite all the data that Lockyer gathered and analysed, the claim that sunspot cycles were to blame for famines was scientifically unsustainable. However, his expeditions and observations helped initiate the tradition of international collaboration in the collection of meteorological data, and led to the establishment of several modern astronomical observatories in India.

Despite his key role in the professionalization of science, Lockyer continued to display many attributes of the generalist amateur. This, as Meadows points out, is what makes his life and career so interesting. The book's foreword, written by Nature's editor-in-chief Philip Campbell, highlights the breakthroughs and controversies - such as 'smart' drugs, sequencing of the human genome and Dolly the sheep - in which Lockyer's enduring institutional legacy continues to play a part. Meadows's biography constitutes an important, absorbing and eminently readable narrative of Lockyer's role in transforming the practice and social organization of late Victorian science.

Zaheer Baber is professor of sociology at the University of Toronto, Ontario M5S 2J4, Canada, and author of The Science of Empire. e-mail: zaheer.baber@gmail.com 